\title{
Introduction: Women's Religious Freedom and Freedom of Religion or Belief
}

Women's religious freedom deserves special attention as an integral part of freedom of religion or belief (FORB), and likewise FORB deserves special attention as an integral part of women's religious freedom. This issue aims to afford such special attention as it addresses the multiple and intersecting ways that women's religious freedom and FORв have interacted, collided, and colluded. Women's religious freedom has historically been accorded a special status across a variety of religious traditions; it has also been particularly subject to legislative and customary force at international, national and local levels. In international, regional, and national jurisdictions the relationships between the gender dimensions of FORB and the principle of gender equality have become increasingly important and relevant. One can see these relationships in relation to United Nations (UN) treaty bodies, including the Human Rights Committee (HRC), the Committee on the Elimination of Discrimination Against Women (CEDAW) and Committee on the Rights of the Child (CRC); they are also apparent in the European Court of Human Rights (ECtHR) and national courts. Religious and cultural instantiations of gender-based frameworks and practices are subject to challenge and renegotiation at the intersection of contested freedoms. The benefits of clarifying the conceptual and practical relationships between FORB and women's religious freedom is evident in relation to navigating normative stances around gender equality with respect to the socio-political aspects of religion. Some reports have moved to tackle these issues head on, notably, Nazila Ghanea's report on Women and Religious Freedom: Synergies and Opportunities, ${ }^{1}$ the United Nations Special Rapporteur on Freedom of Religion or Belief, Ahmed Shaheed's report on freedom of religion or belief and gender equality, ${ }^{2}$ and Marie Juul Peterson's report on Promoting Freedom of Religion or Belief and Gender Equality in the Context of

1 N. Ghanea, Women and Religious Freedom: Synergies and Opportunities (USCIRF, 2017).

2 A. Shaheed, Report of the UN Special Rapporteur on Freedom of Religion or Belief on Gender-based violence and discrimination in the name of religion or belief, presented at the 43rd Session of the Human Rights Council, 24 August 2020. 
Sustainable Development Goals. ${ }^{3}$ All three consider how issues at the intersection of FORB and gender equality might be reasonably approached, as well as what mechanisms and tools are available to address these issues with respect to the greater catalogue of human rights.

Overview of the Special Issue: This collection of essays continues in a similar vein and brings together scholars from intersecting disciplinary fields to provide cultural, religious, and legal analyses of the social systems and contexts where issues of FORB and women's religious freedom overlap. The issue investigates the many facets of this overlapping, often tensional, relationship by engaging the experiences of women as social and political beings who are also rights holders. Previous research addressing the violation of women's rights in the name of religion has ranged broadly. This has included looking at women's status within the family, examining women's rights violations by state and non-state actors, and addressing the topic of women's religious freedom with regard to clothing and symbolic artefacts. This special issue acknowledges the earlier research and offers additional intersectional analyses of contemporary debates, as well as consideration of future interdisciplinary problems drawing from international, regional, and national perspectives.

In this volume's first article Nazila Ghanea contends that, where FORB and women's rights to equality are concerned, there is a misperception that rights are competing and clashing. Ghanea writes that this is in part due to violations of women's rights by state or non-state actors in the name of religion, as well as 'the extensive religiously phrased reservations' to international treaties, particularly to CEDAW by states upon ratification or accession. Ghanea asserts FORB should not be conflated as "right of "religion" as such. An important point highlighted by Ghanea is that religiously phrased reservations and declarations which restrict women's rights also restrict our understanding of FORB itself. Ghanea concludes, one should therefore 'not confuse violations and restrictions in the name of religion-particularly by state actors-and FORB.' Thus Ghanea's article provides a novel reading of FORB and women's rights to equality by addressing overlapping rights concerns and intersectional claims.

Roja Fazaeli and Joel Hanisek's article examines some of the common rationale that often undergirds reservations to CEDAw by Muslim-majority countries. It finds that most reservations are entered in the name of Sharia, with the implied understanding that there is also a simultaneous appeal being made to the preservation of freedom of religion or belief. The article suggests that disentangling this implied status requires additional conceptual interrogation,

3 M.J. Peterson, Promoting Freedom of Religion or Belief and Gender Equality in the Context of Sustainable Development Goals (Danish Institute for Human Rights, February 2020). 
with as special appeal that more definitional clarity be offered in contextual invocations of Sharia for social, legal or political purposes. The article then narrows its focus to critically examine the current state of Iran's engagement with CEDAW as a case study in point of kind.

Amal Idrissi, in her pioneering article, explores the notion of freedom of religion both lexically and contextually. She traces the transformation of the Arabic word hurriyya (freedom) historically from the 19th century onwards through the work of influential Muslim reformist thinkers Rifa'a al-Tahtawi, Jamal al-Din al-Afghani and Muhammad Abduh, as well as the Lebanese Christian Scholar Butrus al-Bustani. Contextually, Idrissi explores the constitutional provision of Islam as religion of the state in Muslim majority contexts of Algeria, Tunisia and Morocco. She makes an important distinction by highlighting the differences between constitutions declaring Islam as the religion of state and those stating sharia as a source of law or legislation. Notions of "Freedom of Religion" and "Freedom of Conscience" are also explored in their historical, linguistic, geographical and constitutional contexts. Another important point highlighted by Idrissi is the role judges play in interpreting law and specifically religious law in these contexts. Idrissi dedicates the final sections of her article to domestic legal provisions in regard to women's rights, such as marriage of a Muslim to a non-Muslim and laws concerning child custody. These examples demonstrate areas where Muslim law (as interpreted by judges) contradict international human rights norms of religious freedoms, particularly as it impacts women's human rights including their right to freedom of religion or belief.

Linda Hogan's article explores Irish women's hard won access to their reproductive rights and the legacy of religion in Ireland. Through a study of the 8th Amendment to the Irish Constitution in 1983 and its subsequent repeal in 2018, Hogan investigates the dominance and decline of religion in Irish public and political life. Hogan's main concerns in this paper are around women's rights to abortion vis a vis claims to freedom of conscience, religion or belief, including conscientious objection, 'particularly in light of the continuing institutional power of the Catholic church in the provision of healthcare, and in the context of the growing transnational religious-freedom litigation focused on restricting reproductive rights.' She also connects these to broader national and international discussions and political changes on religious majoritarianism, pluralism and minority rights.

Eva Brems' article Hidden under Headscarves?-Women and Religion in the case law of the European Court of Human Rights adopts a broad perspective on European Court of Human Right's cases regarding "gender \& religion." Some of these include rulings on Muslim women's dress, while others encompass 
religious pluralism. Such Court rulings have faced some criticism centred on religious minority rights claims and equality arguments, particularly the suggestion of their stereotypical views on Muslim women. It is important to note, as Brems highlights, that there have been changes in the Court's approach 'to the gender implications of Muslim women's religious dress.' However, the article suggests that while the headscarf is no longer automatically equated with a denial of gender equality in contexts related to Islam there remains a prevalent denial of women's agency and paternalistic views around the protection of women that mitigate against women's empowerment, agency, and choice. As a result Brems invites us and the Court to take a another look at women and religion and searches for 'good intersectionality practices' in the Court's women \& religion case law in order to suggest ways to prioritize the specific needs of women against a more abstract notion of gender equality.

Together these articles represent novel and fresh takes on how gender equality, FORB, and women's religious freedom, in particular, may currently be understood to coexist, and chafe against each other, as related goods within the firmament of human rights. Ranging across different regions, religions, and various historical time periods, these essays eschew easy answers, but will keep readers well focused on the centrality and importance of acknowledging and respecting the autonomy and agency of women, especially in relation to the changing shapes of legal traditions, cultural forms, and political programmes.

Roja Fazaeli | ORCID: 0000-0002-1060-7231

Associate Professor in Islamic Civilisations, Trinity College Dublin, Ireland fazaelr@tcd.ie

\author{
Mine Yildirim \\ Head of the Freedom of Belief Initiative \& Head of the Eurasia Civil Society \\ Program at Norwegian Helsinki Committee \\ yildirim.mine@gmail.com
}

